\title{
Enterobacteriaceae ISOLATES FROM THE ORAL CAVITY OF WORKERS IN A BRAZILIAN ONCOLOGY HOSPITAL
}

\author{
Lara Stefânia Netto de Oliveira LEÃo-VASCONCELOS(1), Ana Beatriz Mori LIMA(2), Dayane de Melo COSTA(3), Larissa Oliveira ROCHA-VILEFORT(3), \\ Ana Claúdia Alves de OLIVEIRA(4), Nádia Ferreira GONÇALVES(5), José Daniel Gonçalves VIEIRA(1) \& Marinésia Aparecida PRADO-PALOS(3)
}

\begin{abstract}
SUMMARY
The evaluation of workers as potential reservoirs and disseminators of pathogenic bacteria has been described as a strategy for the prevention and control of healthcare-associated infections (HAIs). The aim of this study was to evaluate the presence of Enterobacteriaceae in the oral cavity of workers at an oncology hospital in the Midwest region of Brazil, as well as to characterize the phenotypic profile of the isolates. Saliva samples of 294 workers from the hospital's healthcare and support teams were collected. Microbiological procedures were performed according to standard techniques. Among the participants, 55 (18.7\%) were colonized by Enterobacteriaceae in the oral cavity. A total of 64 bacteria were isolated, including potentially pathogenic species. The most prevalent species was Enterobacter gergoviae (17.2\%). The highest rates of resistance were observed for $\beta$-lactams, and $48.4 \%$ of the isolates were considered multiresistant. Regarding the enterobacteria isolated, the production of ESBL and KPC was negative. Nevertheless, among the 43 isolates of the CESP group, $51.2 \%$ were considered AmpC $\beta$-lactamase producers by induction, and $48.8 \%$ were hyper-producing mutants. The significant prevalence of carriers of Enterobacteriaceae and the phenotypic profile of the isolates represents a concern, especially due to the multiresistance and production of AmpC $\beta$-lactamases.
\end{abstract}

KEYWORDS: Carriers; Enterobacteriaceae; Multidrug-resistant; Beta-lactamases.

\section{INTRODUCTION}

Healthcare-associated infections (HAIs) are transmissible and result from the interaction of multiple factors which work differently in the infection chain ${ }^{9}$. In this context, workers have been indicated as possible disseminators of pathogenic microorganisms in and out of the hospital environment ${ }^{17,29}$.

In their daily work, these workers are exposed to various health risks, such as areas of insalubrity, contact with sick people and various biological agents. These factors, associated with the time spent in the institution, type of care provided and lack of adherence to biosecurity measures, make these workers susceptible to colonization by different microorganisms, including enteric bacteria, such as Enterobacteriaceae $e^{9,32}$.

Once colonized, the carrier condition is established, and these individuals begin to work directly in the transmission chain of HAIs, both as reservoirs and sources of infectious agents. The dissemination of microorganisms into the environment and into susceptible hosts increases the risk of infection and the occurrence of outbreaks ${ }^{9,29}$.

The investigation of workers as carriers of pathogenic and multiresistant bacteria has been cited as a strategy to prevent and control HAIs. The majority of studies available on the topic report that HAIs are primarily associated with microbial transmission through the hands and nasal cavities of the workers ${ }^{4,12,19}$. Yet the colonization of other anatomical sites also contributes to the spread of pathogens $s^{9,15,35}$.

The mouth is an important location for investigation, since its anatomical and physiological characteristics make it a favorable location for microbial proliferation ${ }^{13,21}$. Microorganisms can spread from the mouth via aspiration through oropharyngeal secretions or transmission via saliva droplets from speaking, coughing, sneezing or breathing ${ }^{9,13}$.

According to literature, Staphylococcus aureus is the most commonly studied colonization agent among workers at healthcare institutions $s^{4,12,29}$. Studies on colonization by gram-negative bacteria, especially Enterobacteriaceae, are rare, yet it is important to learn more regarding carriers in public health settings.

Enterobacteriaceae is a family of gram-negative rods (GNR) that have stood out in the healthcare environment due to the variety of severe infections they can cause, and their high rates of antimicrobial resistance ${ }^{35}$. One aggravating factor in this scenario has been the

(1) Public Health and Tropical Pathology Institute, Federal University of Goiás, Rua 235 s/n, Setor Universitário, 74605-050 Goiânia, Goiás, Brazil.

(2) Central Public Health Laboratory, Dr. Giovanni Cysneiros/LACEN, State Department of Goiás, Rua SC1 299, Parque Santa Cruz, $74860-270$ Goiânia, Goiás, Brazil.

(3) Nursing School, Federal University of Goiás, Rua 227 s/n, Setor Universitário, 74605-080 Goiânia, Goiás, Brazil.

(4) Biomedicine Department, Pontifical Catholic University of Goiás, Rua 232 nº 128, Setor Universitário, 74605-010 Goiânia, Goiás, Brazil.

(5) Emergency Hospital of Goiânia, State Department of Goiás, Av. 31 de março sın, Setor Pedro Ludovico, 74820-200 Goiânia, Goiás, Brazil.

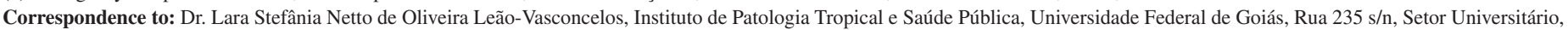
74605-050 Goiânia Goiás, Brasil. Phone: 55.62.3209-6108, Fax: 55.62.3209-6363. E-mail: larastefania@yahoo.com.br 
LEÃO-VASCONCELOS, L.S.N.O.; LIMA, A.B.M.; COSTA, D.M.; ROCHA-VILEFORT, L.O.; OLIVEIRA, A.C.A.; GONÇALVES, N.F.; VIEIRA, J.D.G. \& PRADO-PALOS, M.A. Enterobacteriaceae isolates from the oral cavity of workers in a Brazilian oncology hospital. Rev. Inst. Med. Trop. Sao Paulo, 57(2): 121-7, 2015.

emergence of $\beta$-lactamase-producing strains, which constitute the most important mechanism of resistance to $\beta$-lactam antimicrobials ${ }^{35}$.

In light of the lack of studies on the theme, this study was designed to increase knowledge regarding the colonization of the oral cavity of workers by Enterobacteriaceae. The objective of this study was to analyze the presence of Enterobacteriaceae in the oral cavity of workers in an oncology hospital, as well as to characterize the phenotypic profile of the isolates.

\section{MATERIAL \& METHODS}

Study type and location: This was a cross-sectional, descriptive epidemiological study, performed with workers in a large oncology hospital that is a reference for cancer treatment. On average, this hospital treats 28,000 patients every month, who are predominantly users of the Brazilian Unified Health System (SUS, as per its acronym in Portuguese), and performs 67,000 procedures, including: consultations, hospitalizations, surgeries, treatments and exams, among others.

The present study was carried out between May 2009 and November 2010 , and is part of a larger surveillance study on the colonization of workers by pathogenic microorganisms. The research proposal was approved by the hospital's Ethics Research Committee (ProtocolCEPACCG/040/08). All the workers were informed regarding the objectives of the study, as well as the collection procedures. The workers who agreed to participate in the study signed the Free and Informed Consent Form (FICF).

Study population: The study population consisted of 294 workers, including 149 members of the healthcare team and 145 workers from the support sector. The healthcare team was comprised of physicians, nurses, nursing technicians and assistants, pharmacists, physicists, physical therapists, nutritionists and psychologists. These professionals worked in the following departments: Surgery Center, Hospital Infection Control, Dressing, Endoscopy, Nursing Stations, First Aid, Adult and Child Chemotherapy, Radiotherapy, Rehabilitation and Physiotherapy, Intensive Therapy and Bone Marrow Transplant.

The support team was comprised of workers from the following departments: Materials and Sterilization, Sterilization and Cleaning, Nutrition and Diet and Clothes/Materials Reprocessing. The participants were listed and codified based on the information obtained at the institution.

These workers were chosen because they were considered to be directly responsible for patient healthcare, removal of dirt and contamination from the environment, preparation and distribution of food, as well as reprocessing of materials and clothing used in the hospital.

The following inclusion criteria were observed: belonging to one of the professional categories cited above and working in one of the chosen sectors during the study period. Workers who were using antimicrobials, or who had collected specimens seven days prior to data collection for this study, were excluded from participating in the study.

Collection procedures: The study had three phases: the first entailed inviting the workers to participate, clarifications regarding the research, and signing the FICF; the second phase entailed application of a questionnaire for collection of sociodemographic, professional, disease/infection and behavioral characteristics of the workers; and the third phase entailed collection of unstimulated saliva samples ${ }^{18}$. All three phases were performed on the same day.

Collection and processing of the samples: One unstimulated saliva sample ( 0.7 to $1.0 \mathrm{~mL}$ ) was collected from each participant and each was placed in a disposable and sterilized plastic (polypropylene) container, totaling 294 samples. Collection was done by the worker, and supervised by the study researchers and their assistants ${ }^{18}$. The samples were homogenized (vortex) and $20 \mu \mathrm{L}$ aliquots were sowed in a selective culture of MacConkey agar, followed by incubation at $35^{\circ} \mathrm{C}$ for $24-48 \mathrm{~h}^{35}$.

Isolation and identification of the Enterobacteriaceae: The microbiological procedures for the isolation and identification of microorganisms were performed according to standardized and countersigned techniques ${ }^{35}$. Standard strains from the American TypeCulture Collection (Escherichia coli ATCC@ 2592 and Klebsiella pneumoniae ATCC® 700603) were used as quality control for the tests performed.

The bacteria isolates in MacConkey agar were previously identified, according to the macroscopic and microscopic characteristics (Gram staining) of the colonies. Differentiation of the species was done through a series of biochemical screening (carbohydrate fermentation in Kligler Iron agar and cytochrome oxidase production) and classification tests (indole production; presence of motility; ornithine, arginine and lysine decarboxylation; citrate utilization; phenylalanine deaminase production; urease production; hydrogen sulfide production and methyl red test).

Profile of susceptibility to anti-infective agents: The susceptibility profile of the isolates was evaluated using the method of disc diffusion in agar (antibiogram), according to recommendations of the Clinical and Laboratory Standards Institute, state of Pennsylvania, USA ${ }^{5}$. The microorganisms that were simultaneously resistant to two or more different classes of antimicrobials were considered multiresistant ${ }^{28}$.

In total, 16 antimicrobial agents were evaluated: amoxicillin/ clavulanic acid, aztreonam, cefepime, cefotaxime, cefoxitin, cefpodoxime, ceftazidime, ceftriaxone, ciprofloxacin, gentamicin, imipenem, levofloxacin, meropenem, piperacillin-tazobactam, tetracycline and trimethoprim-sulfamethoxazole 5 .

Phenotypic detection of $\boldsymbol{\beta}$-lactamases production: The three types of $\beta$-lactamases studied were: inducible chromosomal AmpC $\beta$-lactamase, Extended Spectrum $\beta$-lactamase (ESBL) and Klebsiella pneumoniae Carbapenemase (KPC). Phenotypic tests were performed in two stages, screening and confirmation, according to standardized techniques.

The screening for the resistance phenotypes was performed with an antibiogram by disc diffusion, through the use of tracer drugs ${ }^{5}$. Production of AmpC and ESBL was confirmed by the disc approximation test $\mathrm{t}^{22}$ and the production of KPC by the modified Hodge test ${ }^{5}$.

AmpC: Isolates belonging to the CESP group (Citrobacter spp., Enterobacter spp., Serratia spp., Providencia spp.) which were sensitive 
LEÃO-VASCONCELOS, L.S.N.O.; LIMA, A.B.M.; COSTA, D.M.; ROCHA-VILEFORT, L.O.; OLIVEIRA, A.C.A.; GONÇALVES, N.F.; VIEIRA, J.D.G. \& PRADO-PALOS, M.A. Enterobacteriaceae isolates from the oral cavity of workers in a Brazilian oncology hospital. Rev. Inst. Med. Trop. Sao Paulo, 57(2): 121-7, 2015.

to cefoxitin in the antibiogram (screening) were submitted to the test by disc approximation (confirmatory), in which a cefoxitin disc $(30 \mu \mathrm{g})$ was placed in the center of the plate, $20 \mathrm{~mm}$ (center to center) away from a ceftriaxone disc $(30 \mu \mathrm{g})$ and from a ceftazidime disc $(30 \mu \mathrm{g})$. The plate was incubated at $35^{\circ} \mathrm{C}$ for $18-24 \mathrm{~h}$. Cefoxitin works as an inducer of the AmpC enzyme and the reading was considered positive, when the flatness of the halo around the ceftriaxone and/or ceftazidime disc was observed ${ }^{22}$.

ESBL: The screening of the ESBL phenotype was done with the antibiogram for the isolates identified as Escherichia coli, Klebsiella pneumonie and Klebsiella oxytoca, through five substrates: aztreonam $30 \mu \mathrm{g}$, cefotaxime $30 \mu \mathrm{g}$, cefpodoxime $10 \mu \mathrm{g}$, ceftazidime $30 \mu \mathrm{g}$ and ceftriaxone $30 \mu \mathrm{g}$. The isolates that showed resistance to at least one of the antimicrobials used in the screening were submitted to the confirmatory test by disc approximation or double disc synergism. In this test, one amoxicillin/clavulanic acid disc $(20 \mu \mathrm{g} / 10 \mu \mathrm{g})$ was placed in the center of the plate and $20 \mathrm{~mm}$ (center to center) away from an aztreonam disc $(30 \mu \mathrm{g})$ and from a ceftazidime disc $(30 \mu \mathrm{g})$. The plate was incubated at $35^{\circ} \mathrm{C}$ for $18-24 \mathrm{~h}$. The test was considered positive when there was an increase or distortion of the inhibition zone (ghost zone) between any antimicrobial marker and the amoxicillin/clavulanic acid disc ${ }^{22}$.

KPC: Enterobacteriaceae, mainly Klebsiella pneumoniae, with resistance to some third generation cephalosporins (ceftazidime, ceftriaxone or cefotaxime) and to some carbapenem (imipenem or meropenem) in the antibiogram, were subjected to the modified Hodge test (confirmatory). To carry out the modified Hodge test, an E. coli ATCC® 25922 inoculum corresponding to a $0.5 \mathrm{McFarland}$ standard was prepared and sowed over the surface of a Mueller-Hinton agar plate. A $10 \mu \mathrm{g}$ meropenem disc was placed in the center of the plate. With the aid of an inoculation loop, three to five freshly-grown colonies $(24 \mathrm{~h})$ from the test sample were sowed from the center of the meropenem disc to the periphery of the Petri plate, in order to trace out an imaginary line of 20 to $25 \mathrm{~mm}$. After incubation at $35^{\circ} \mathrm{C}$ for $16-20 \mathrm{~h}$, the test was considered positive when there was growth of the E. coli ATCC® 25922 strain in the meropenem inhibition zone (distortion of the inhibition zone) $)^{5}$.

Processing and analysis of results: The data collected from the workers were codified and organized in the IBM software program Statistical Package for Social Sciences (SPSS) for Windows (version 18.0), then analyzed through descriptive analysis.

\section{RESULTS}

Colonized workers: During the study period (18 months), the oral cavities of 55 (18.7\%) subjects were colonized by Enterobacteriaceae; of these workers, 36 were healthcare providers, and 19 (13.1\%) were support staff. Among the colonized individuals, 49.1\% (27/55) carried enterobacteria with a profile of multiresistance to antimicrobial agents, $90.9 \%(50 / 55)$ carried only one species of enterobacteria, and $9.1 \%$ $(5 / 55)$ carried two to three species simultaneously, that is to say, they were colonized by multiple species of Enterobacteriaceae.

Bacterial isolates: 64 enterobacteria of different genera and species were isolated (Table 1). The most common genera were Enterobacter (46.9\%), Klebsiella (18.8\%) and Citrobacter (17.2\%), whereas the most prevalent species was Enterobacter gergoviae (17.2\%). Potentially pathogenic bacteria were also isolated, including Klebsiella pneumoniae
(12.5\%), Klebsiella oxytoca (6.2\%), Escherichia coli (6.2\%) and Serratia marcescens $(3.1 \%)$.

Table 1

Species of Enterobacteriaceae $(\mathrm{n}=64)$ isolated from the oral cavity of workers in an oncology hospital. Goiânia, Goiás, 2009-2010

\begin{tabular}{lcc}
\hline Microorganism & Isolates (f) & Total (\%) \\
\hline Enterobacter gergoviae & 11 & 17.2 \\
Enterobacter sakasaki & 08 & 12.5 \\
Enterobacter aerogenes & 08 & 12.5 \\
Klebsiella pneumoniae & 08 & 12.5 \\
Citrobacter koseri & 07 & 10.9 \\
Pantoea agglomerans & 05 & 7.8 \\
Klebsiella oxytoca & 04 & 6.2 \\
Escherichia coli & 04 & 6.2 \\
Enterobacter cloacae & 03 & 4.7 \\
Citrobacter amalonaticus & 02 & 3.1 \\
Citrobacter freundii & 02 & 3.1 \\
Serratia marcescens & 02 & 3.1 \\
\hline Total & 64 & 100
\end{tabular}

Profile of antimicrobial susceptibility: Table 2 shows the profile of susceptibility of the enterobacteria to the 16 antimicrobial agents: $57.8 \%$ (37/64) of the isolates were resistant to amoxicillin/clavulanic acid, $45.3 \%$ $(29 / 64)$ to cefoxitin, $15.6 \%$ (10/64) to tetracycline and $10.9 \%(7 / 64)$ to cefpodoxime. In addition, all $(100.0 \%)$ of the enterobacteria were sensitive to cefepime, ciprofloxacin, gentamicin, imipenem, meropenem and levofloxacin.

Forty-two $(65.6 \%)$ isolates presented some type of resistance, and $31(48.4 \%)$ were resistant to two or more classes of antimicrobials, characterizing a profile of multiresistance. Of these, $6.4 \%(2 / 31)$ were simultaneously resistant to three, and $6.4 \%(2 / 31)$ to four different classes.

Phenotypic production of $\boldsymbol{\beta}$-lactamases: In this study, the phenotypic production of Inducible Chromosomal AmpC $\beta$-lactamase was researched among the 43 (67.2\%) CESP group isolates identified: (Citrobacter spp., Enterobacter spp., Serratia spp., Providencia spp.). All were positive for AmpC production. However, these microorganisms showed different mechanisms. Twenty-two (51.2\%) isolates were sensitive to cefoxitin (tracer) and positive for the confirmation test (disc approximation) of production of the enzyme, characterizing an induction mechanism. Nevertheless, $21(48.8 \%)$ of the isolates were resistant to cefoxitin, indicating the presence of mutant strains that hyper-produce the AmpC enzyme (Table 3).

The Extended Spectrum $\beta$-lactamase (ESBL) was studied for the $16(25.0 \%)$ isolates identified as E. coli and Klebsiella spp.; however, none was a producer of the enzyme. All of the enterobacteria $(100.0 \%)$ were negative for the production of KPC-type carbapenemase (Table 3). 
LEÃO-VASCONCELOS, L.S.N.O.; LIMA, A.B.M.; COSTA, D.M.; ROCHA-VILEFORT, L.O.; OLIVEIRA, A.C.A.; GONÇALVES, N.F.; VIEIRA, J.D.G. \& PRADO-PALOS, M.A. Enterobacteriaceae isolates from the oral cavity of workers in a Brazilian oncology hospital. Rev. Inst. Med. Trop. Sao Paulo, 57(2): 121-7, 2015.

Table 2

Profile of antimicrobial susceptibility of Enterobacteriaceae $(n=64)$ isolates from the oral cavity of workers in an oncology hospital. Goiânia, Goiás, 20092010

\begin{tabular}{|c|c|c|c|c|}
\hline \multirow{2}{*}{ Antimicrobial Agent } & $\mathrm{S}$ & I & $\mathrm{R}$ & \multirow{2}{*}{$\begin{array}{c}\text { Total R } \\
(\%)\end{array}$} \\
\hline & \multicolumn{3}{|c|}{ Isolates (f) } & \\
\hline Amoxicillin-clavulanic acid & 18 & 9 & 37 & 57.8 \\
\hline Cefoxitin & 35 & 0 & 29 & 45.3 \\
\hline Tetracycline & 53 & 1 & 10 & 15.6 \\
\hline Cefpodoxime & 49 & 8 & 7 & 10.9 \\
\hline Trimetoprim-sulfmetoxazol & 61 & 1 & 2 & 3.1 \\
\hline Ceftazidime & 63 & 0 & 1 & 1.6 \\
\hline Ceftriaxone & 63 & 0 & 1 & 1.6 \\
\hline Piperacillin tazobactam & 63 & 0 & 1 & 1.6 \\
\hline Cefotaxime & 63 & 1 & 0 & 0 \\
\hline Aztreonam & 63 & 1 & 0 & 0 \\
\hline Cefepime & 64 & 0 & 0 & 0 \\
\hline Ciprofloxacin & 64 & 0 & 0 & 0 \\
\hline Gentamicin & 64 & 0 & 0 & 0 \\
\hline Imipenem & 64 & 0 & 0 & 0 \\
\hline Levofloxacin & 64 & 0 & 0 & 0 \\
\hline Meropenem & 64 & 0 & 0 & 0 \\
\hline
\end{tabular}

Table 3

$\beta$-lactamases produced by Enterobacteriaceae $(n=64)$ isolated from the oral cavity of workers in an oncology hospital. Goiânia, Goiás, 2009-2010

\begin{tabular}{lccc}
\hline \multirow{2}{*}{ Enzymes } & $\begin{array}{c}\text { Isolates } \\
\text { evaluated }\end{array}$ & $\begin{array}{c}\text { Positive } \\
\text { isolates }\end{array}$ & Total \\
\cline { 2 - 4 } & $\mathbf{( f )}$ & $(\mathbf{f})$ & $\mathbf{( \% )}$ \\
\hline KPC & 64 & 0 & 0 \\
AmpC/induction & 43 & 22 & 51.2 \\
AmpC/hyperproduction & 43 & 21 & 48.8 \\
ESBL & 16 & 0 & 0 \\
\hline
\end{tabular}

KPC: Klebsiella pneumoniae Carbapenemase; ESBL: Extended Spectrum $\beta$-lactamase.

\section{DISCUSSION}

A large number of HAIs have an endogenous origin and are difficult to prevent. However, the number of preventable infections is significant, especially those resulting from the cross-transmission of microorganisms ${ }^{9}$. Thus, the problem of colonization of healthcare workers by pathogenic and multiresistant bacteria is clear ${ }^{4,17}$.

In health services, the multidisciplinary team deserves special attention because it is the base level of care provided to patients. The support team maintains the infrastructure necessary for the hospital's operation ${ }^{34}$. These workers can spread microorganisms, and their identification as possible reservoirs and sources of infectious agents is an important measure to prevent and control HAIs ${ }^{6}$.

Nevertheless, studies on the oral cavity and gram-negative bacteria of clinical and epidemiological importance are rare in literature. Despite the limits, these studies are very important for the control of microbial dissemination, and consequently the control of infection rates. The oral cavity can serve as a potential reservoir of Enterobacteriaceae, which are spread to the environment and to susceptible individuals through saliva. This fact becomes more important when considering the hospital environment, as most Enterobacteriaceae infections take place in this setting ${ }^{13,35}$.

The condition of being a carrier is also damaging to the health of the worker. In a situation of defense mechanism imbalance, endogenous microorganisms can unleash severe infections ${ }^{9,35}$. Hosting enterobacteria in the oral cavity is a predisposing and aggravating factor for many oral and systemic diseases ${ }^{11,26}$.

In this study, the prevalence of colonization in the oral cavity by Enterobacteriaceae was $18.7 \%$; however, individual analysis of the groups of workers showed that $24.2 \%$ of the healthcare workers and $13.1 \%$ of the support workers were carriers.

A similar study performed with 278 members of a healthcare team at a university hospital found a $69.6 \%$ colonization rate by gram-negative bacteria (GNB) (enterobacteria and/or non-fermenters) ${ }^{20}$. In studies with immunocompromised individuals, the presence of Enterobacteriaceae in the oral cavity varied from $32.5 \%$ to $60.7 \%^{10,21}$. In another study, the colonization rate of the oral cavity by enterobacteria and/or Pseudomonas spp. was $51.0 \%{ }^{24}$.

The prevalence of colonization observed in this study was lower than those found in other studies involving the oral cavity. Nevertheless, this data can be considered relevant, because Enterobacteriaceae are enteric microorganisms that do not normally inhabit the oral cavity ${ }^{13}$. The natural habitat of this family of coliforms is the intestinal tract of humans and animals, being among the primary agents of HAIs, and responsible for a variety of clinically important illnesses, such as infections of the urinary tract, respiratory tract, wounds, central nervous system and bloodstream ${ }^{35}$.

Among the colonized study subjects, a greater prevalence was observed for the healthcare team $(24.2 \%)$ in comparison to the support team. This may be explained by the fact that these workers are responsible for healthcare, and are frequently exposed to direct and indirect contact with patients and biological agents. Additionally, many of these professionals work in other healthcare institutions, a factor that favors colonization by diverse agents, including multiresistant bacteria ${ }^{32}$.

Colonization is a dynamic process dependent upon various factors ${ }^{35}$. Conditions such as hospitalization, compromised immunological response, inadequate hygiene habits, salivation reduction and natural chewing movements favor the colonization and proliferation of Enterobacteriaceae in the oral cavity ${ }^{1}$. Furthermore, there is a hypothesis that the incidence of these microorganisms in the mouth is also related to the presence of coliforms in water and foods ${ }^{27}$. 
LEÃO-VASCONCELOS, L.S.N.O.; LIMA, A.B.M.; COSTA, D.M.; ROCHA-VILEFORT, L.O.; OLIVEIRA, A.C.A.; GONÇALVES, N.F.; VIEIRA, J.D.G. \& PRADO-PALOS, M.A. Enterobacteriaceae isolates from the oral cavity of workers in a Brazilian oncology hospital. Rev. Inst. Med. Trop. Sao Paulo, 57(2): 121-7, 2015.

Another concerning factor is that $9.1 \%$ of the carriers were colonized by different species of enterobacteria. In one study performed with the healthcare team of a teaching hospital, $49.2 \%$ of the workers were multicolonized by $\mathrm{GNB}^{20}$. The large microbial diversity of the oral cavity reflects, among other factors, the presence of the dental biofilm, which enables special conditions for survival and growth ${ }^{14}$. Additionally, anatomical and physiochemical properties of the oral cavity make it an ecosystem that is highly complex, heterogeneous and distinct from all others $^{13,21}$

In regard to the phenotypic characterization of the isolated microorganisms, the most common bacteria were Enterobacter, Klebsiella and Citrobacter, and the most prevalent species was Enterobacter gergoviae (17.2\%). In one study with health workers, the genera Enterobacter and Klebsiella were also described as the most frequent in the oral cavity ${ }^{20}$. Similar data were reported in another study, in which Enterobacter cloacae $(31.0 \%)$ was the most isolated enterobacteria among individuals in dental treatment, followed by Klebsiella pneumoniae $(18.3 \%)^{24}$.

The species of enterobacteria isolated in this study are opportunistic hospital pathogens, which eventually may be found in the oral cavity and in subgingival samples of healthy individuals ${ }^{24,26,35}$. Bacteria known for their virulence and capacity to cause severe infections (Klebsiella, Escherichia, Serratia) were isolated ${ }^{30}$.

The species E. gergoviae can be isolated from environmental sources, as well as the respiratory and urinary tracts and the blood of human beings. This microorganism is the most common cause of nosocomial bacteremia. Its presence in the oral cavity constitutes a risk factor for infections such as severe adult periodontitis and pneumonias ${ }^{24,26,35}$.

The highest resistance rates were observed for the group of $\beta$-lactams: amoxicillin/clavulanic acid (57.8\%), cefoxitin (45.3\%) and cefpodoxime (10.9\%) (Table 2). The $\beta$-lactams constitute the most traditional antimicrobial agents employed in the treatment of infections. The increase of resistance in gram-negative bacteria is due to the production of $\beta$-lactamase enzymes ${ }^{28,31}$, as verified by this study.

High rates of resistance to quinolones, aminoglycosides and $\beta$-lactams have been reported at various institutions ${ }^{23,30}$. Yet, in this study, all of the isolates were sensitive to quinolones (ciprofloxacin and levofloxacin), gentamicin, cefepime and carbapenems (imipenem and meropenem). One study that evaluated the antimicrobial susceptibility of enterobacteria isolated from the oral cavity also found $100.0 \%$ sensitivity to quinolones ${ }^{25}$.

Sensitivity to quinolones and aminoglycosides is an important finding. These pharmaceuticals are the drug of choice for the treatment of a variety of infections by gram-negative rods, including respiratory infections caused by isolated producers of AmpC $\beta$-lactamase ${ }^{23}$.

Cefepime is also active against producing strains of AmpC $\beta$-lactamase, and the first choice therapy against this type of microorganism ${ }^{23}$. Carbapenems are a broad spectrum antimicrobial group, especially used in situations of severe infection by multiresistant enterobacteria ${ }^{3}$.

Of the workers studied, $49.1 \%$ were colonized by multiresistant enterobacteria. Isolates with a multiresistant profile correspond to
$48.4 \%$ of the total enterobacteria, with some (6.4\%) being resistant to four distinct classes of antimicrobials. This result represents a concern, since these colonization agents were isolated from healthy carriers. As a consequence of this profile, various antimicrobials become less active, reducing therapeutic options and increasing the clinical impact of infectious diseases ${ }^{7}$.

In the last few years, Enterobacteriacae have been shown to be resistant to a variety of antimicrobial agents. This increase in resistance is primarily related to the frequent use of antimicrobials and to how easy it is for these microorganisms to build up resistance ${ }^{22,31}$. This profile has been particularly observed in the hospital environment, where outbreaks of infections of $\beta$-lactamases-producing enterobacteria are described ${ }^{8,33}$.

In regard to $\beta$-lactamases of clinical importance, the phenotypic production of ESBL and KPC was not observed. Yet, among the CESP group, all of the isolates were producers of AmpC $\beta$-lactamases. This increased production was different between the isolates due to a mechanism of induction and mutation.

In the group of AmpC producing bacteria, 51.2\% of the isolates were sensitive to cefoxitin (tracer) in the antibiogram, and subsequently were confirmed to produce AmpC $\beta$-lactamases. This means that these isolates only express resistance when exposed to an antimicrobial inducer (induction), that is, when the therapy is started. In these cases, therapeutic failure can occur during treatment ${ }^{23}$.

On the other hand, $48.8 \%$ of the CESP isolates were resistant to cefoxitin in the antibiogram, and therefore considered mutant strains. As the result of a mutation, this type of isolate permanently hyperproduces AmpC $\beta$-lactamases ${ }^{31}$. This phenomenon results in the constant production of high levels of AmpC $\beta$-lactamase regardless of exposure to an induction agent. Enterobacteriaceae mutants may be selected from populations of inducible strains during therapy by using weak inducing antimicrobial agents ${ }^{23}$.

The AmpC $\beta$-lactamase enzyme belongs to the $\mathrm{C}$ molecular class and functional group 1 , does not suffer the action of $\beta$-lactamase inhibitors and has inducible expression, being produced in low quantities (intrinsic mechanism) by the CESP group. AmpC-producing strains are intrinsically resistant to penicillin, cephalosporin and monobactams ${ }^{31}$.

In healthcare institutions, the prevalence of AmpC-producing strains is variable, and rates of up to $22.7 \%$ may be found ${ }^{16}$. Many intensive care units have reported outbreaks of Enterobacteriaceae that produce inducible AmpC, which stands out for its difficult treatment due to the profile of multiresistance of the isolates ${ }^{2}$.

In this study, the prevalence of carriers of Enterobacteriaceae among the workers at the institution investigated was considered to be significant and the phenotypic profile of the isolates was rather concerning, as it features multiresistant colonization agents and AmpC $\beta$-lactamase producers.

It is believed that the detection of multiresistant Enterobacteriaceae in the oral cavity of the workers at this institution will permit the tracing and identification of carriers, as well as knowledge of the profile of the colonizing microorganisms, in order to monitor the emergence of 
LEÃO-VASCONCELOS, L.S.N.O.; LIMA, A.B.M.; COSTA, D.M.; ROCHA-VILEFORT, L.O.; OLIVEIRA, A.C.A.; GONÇALVES, N.F.; VIEIRA, J.D.G. \& PRADO-PALOS, M.A. Enterobacteriaceae isolates from the oral cavity of workers in a Brazilian oncology hospital. Rev. Inst. Med. Trop. Sao Paulo, 57(2): 121-7, 2015.

resistance and new pathogens. Additionally, it is hoped that the results may contribute to supporting the identification of contamination routes, and consequently, losses caused by these agents. Such information is also useful to improve healthcare practices, keeping in mind the quality of life of the worker, healthcare service users and the community in general, in consonance with the principles of safety.

\section{RESUMO}

\section{Enterobacteriaceae isoladas da cavidade bucal de trabalhadores de hospital oncológico do Centro-Oeste brasileiro}

A investigação de trabalhadores dos serviços de saúde como reservatório e disseminadores de bactérias patogênicas tem sido referida como estratégia de prevenção e controle das infecções relacionadas à assistência à saúde. Este estudo buscou avaliar a presença de Enterobacteriaceae na cavidade bucal de trabalhadores de hospital oncológico do Centro-Oeste brasileiro, bem como caracterizar o perfil fenotípico dos isolados. Foi coletada amostra de saliva de 294 trabalhadores pertencentes às equipes de saúde e de apoio. Procedimentos microbiológicos foram realizados segundo técnicas referendadas. Dentre os participantes, 55 (18,7\%) estavam colonizados por Enterobacteriaceae na cavidade bucal. Foram isoladas 64 bactérias, incluindo espécies potencialmente patogênicas. A espécie mais prevalente foi Enterobacter gergoviae $(17,2 \%)$. As maiores taxas de resistências foram observadas para os $\beta$-lactâmicos e $48,4 \%$ dos isolados foram considerados multirresistentes. Para as enterobactérias pesquisadas, a produção de ESBL e KPC foi negativa. Porém, dentre os 43 isolados do grupo CESP, $51,2 \%$ foram considerados produtores de $\beta$-lactamase AmpC por indução e 48,8\% mutantes hiperprodutores. Considera-se a prevalência de portadores de Enterobacteriaceae significativa e o perfil fenotípico dos isolados preocupante, especialmente pela multirresistência e produção de $\beta$-lactamases AmpC.

\section{ACKNOWLEDGMENTS}

This study was financially supported by the Goiás Research Foundation (FAPEG). Dr. Fabiana Cristina Pimenta, researcher at the Centers for Disease Control and Prevention (CDC), Georgia, USA, contributed as a scientific consultant in the preparation of the manuscript.

\section{REFERENCES}

1. Amaral SM, Cortês ADEQ, Pires FR. Nosocomial pneumonia: importance of the oral environment. J Bras Pneumol. 2009;35:1116-24.

2. Bagattini M, Crispino M, Gentile F, Barretta E, Schiavone D, Boccia MC, et al. A nosocomial outbreak of Serratia marcescens producing inducible Amp C-type beta-lactamase enzyme and carrying antimicrobial resistance genes within a class 1 integron. J Hosp Infect. 2004;56:29-36.

3. Bratu S, Landman D, Alam M, Tolentino E, Quale J. Detection of KPC carbapenemhydrolyzing enzymes in Enterobacter spp. from Brooklyn, New York. Antimicrob Agents Chemother. 2005;49:776-8.

4. Carvalho MJ, Pimenta FC, Hayashida M, Gir E, Silva AM, Barbosa CP, et al. Prevalence of methicillin-resistant and methicillin-susceptible $S$. aureus in the saliva of health professionals. Clinics (Sao Paulo). 2009;64:295-302.

5. Clinical and Laboratory Standards Institute. Performance standards for antimicrobial disk suscetibiliy tests: approved standard. $10^{\text {th }}$ ed. Pennsylvania: CLSI; 2009. p. M02-A10.
6. Colombo AL, Janini M, Salom R, Medeiros EAS, Wey SB, Pignatari ACC. Surveillance programs for detection and characterization of emergent pathogens and antimicrobial resistance. Results from the Division of Infectious Diseases, UNIFESP. An Acad Bras Cienc. 2009;81:571-87.

7. D'Agata EMC, Horn MA, Ruan S, Webb GF, Wares JR. Efficacy of infection control interventions in reducing the spread of multidrug-resistant organisms in the hospital setting. PLOS One. 2012; 7:e30170.

8. Dropa M, Balsalobre LC, Lincopan N, Mamizuka EM, MurakamI T, Cassettari VC, et al. Extended-spectrum beta-lactamases among Enterobacteriaceae isolated in a public hospital in Brazil. Rev Inst Med Trop Sao Paulo. 2009;51:203-9.

9. Fernandes AT, Filho NR, Barroso EAR. Conceito, cadeia epidemiológica das infecções hospitalares e avaliação custo-benefício das medidas de controle. In: Fernandes AT, Fernandes MOV, Filho NR. Infecção hospitalar e suas interfaces na área de saúde. São Paulo: Atheneu; 2000. p. 215-65.

10. Gaetti-Jardim E Jr, Nakano V, Wahasugui TC, Cabral FC, Gamba R, Avila-Campos MJ. Occurrence of yeasts, enterococci and other enteric bacteria in subgingival biofilm of HIV-positive patients with chronic gingivitis and necrotizing periodontitis. Braz J Microbiol. 2008;39:257-61.

11. Gomes-Filho IS, Passos JS, Seixas da Cruz S. Respiratory disease and the role of oral bacteria. J Oral Microbiol. 2010;2:5811.

12. Hamdan-Partida A, Sainz-Espuñes T, Bustos-Martínez J. Characterization and persistence of Staphylococcus aureus strains isolated from the anterior nares and throats of healthy carriers in a Mexican community. J Clin Microbiol. 2010;48:1701-5.

13. Jorge AOC. Microbiologia bucal. 3 ed. São Paulo: Santos; 2007. p. 1-12.

14. Kolenbrander PE, Palmer RJ Jr, Periasamy S, Jakubovics NS. Oral multispecies biofilm development and the key role of cell-cell distance. Nat Rev Microbiol. 2010;8:471-80.

15. Lima ABM, Leão LSNO, Oliveira LSC, Pimenta FC. Nasopharyngeal Gram-negative bacilli colonization in Brazilian children attending day-care centers. Braz J Microbiol. 2010;41:24-7.

16. Mohamudha PR, Harish BN, Parija SC. Ampc Beta lactamases among Gram negative clinical isolates from a tertiary hospital, South India. Braz J Microbiol. 2010;41:596602 .

17. Moura JP, Pimenta FC, Hayashida M, Cruz EDA, Canini SRMS, Gir E. A colonização dos trabalhadores de enfermagem por Staphylococcus aureus. Rev Lat Am Enfermagem. 2011;19:325-31.

18. Naunttofte B, Tenovuo J, Lagerlöf F. Secreção e composição da saliva. In: Fejerskov O, Kidd E. Cárie dentária: a doença e seu tratamento clínico. São Paulo: Santos; 2012. p. 7-27.

19. Nogueras M, Marinsalta N, Roussell M, Notario R. Importance of hand germ contamination in health-care workers as possible carriers of nosocomial infections. Rev Inst Med Trop Sao Paulo. 2001;43:149-52.

20. Prado-Palos MA, Gir E, Lima ABM, Leão LSNO, Pimenta FC. Prevalência de bastonetes Gram-negativos isolados da saliva de trabalhadores da saúde. Rev Eletr Enferm. 2011;13:730-4.

21. Rocha CGBB, Reis C, Pimenta FC. Contagem e identificação de microrganismos na saliva de portadores do vírus da imunodeficiência humana antes e após higienização e bochecho com anti-sépticos. Rev Patol Trop. 2006;35:125-33.

22. Rossi F, Andreazzi DB. Resistência bacteriana: interpretando o antibiograma. São Paulo: Atheneu; 2005.

23. Rossi F, Furtado GH, Andrade SS. Medidas de prevenção e controle da resistência microbiana e programa de uso racional de antimicrobianos em serviços de saúde. São Paulo: Universidade Federal de São Paulo; 2007. 
LEÃO-VASCONCELOS, L.S.N.O.; LIMA, A.B.M.; COSTA, D.M.; ROCHA-VILEFORT, L.O.; OLIVEIRA, A.C.A.; GONÇALVES, N.F.; VIEIRA, J.D.G. \& PRADO-PALOS, M.A. Enterobacteriaceae isolates from the oral cavity of workers in a Brazilian oncology hospital. Rev. Inst. Med. Trop. Sao Paulo, 57(2): 121-7, 2015.

24. Santos SSF, Jorge AOC. Presença de Enterobacteriaceae e Pseudomonadaceae na cavidade bucal humana. Rev Odontol UNESP. 1998;27:473-84.

25. Santos SSF, Jorge AOC. Sensibilidade "in vitro" de Enterobacteriaceae e Pseudomonadaceae isoladas da cavidade bucal humana a agentes antimicrobianos. Braz Dental Sci. 1999;2:40-4

26. Santos SSF, Loberto JCS, Martins CAP, Jorge AOC. Prevalência e sensibilidade in vitro de Enterobacteriaceae e pseudomonas isoladas da cavidade oral e bolsa periodontal de pacientes com periodontite crônica. Braz Dental Sci. 2002;5:74-83

27. Sedgley CM, Samaranayake LP. Oral and oropharyngeal prevalence of Enterobacteriaceae in humans: a review. J Oral Pathol Med. 1994;23:104-13.

28. Siegel JD, Rhinehart E, Jackson M, Chiarello L, Healthcare Infection Control Practices Advisory Committee. Management of multidrug resistant organisms in health care settings, 2006. Am J Infect Control. 2007;35(10 Suppl 2):S165-S93.

29. Silva ECBF, Samico TM, Cardoso RR, Rabelo MA, Bezerra Neto AM, de Melo FL, et al. Colonização pelo Staphylococcus aureus em trabalhadores de enfermagem de um hospital escola de Pernambuco. Rev Esc Enferm USP. 2012;46:132-7.

30. Sun J, Hu LF, Wang M, Shi W, Xu XH, Cheng J, et al. Clinical investigation for infections caused by Enterobacteriaceae in intensive care unit of Anhui, China. Braz J Infect Dis. 2012;16:109-10
31. Thomson KS. Extended-spectrum-lactamase, AmpC and carbapenemase issues. J Clin Microbiol. 2010;48:1019-25.

32. Valle ARMC, Feitosa MBF, Araújo VMD, Moura MEB, Santos AMR, Monteiro CFS Representações sociais da biossegurança por profissionais de enfermagem de um serviço de emergência. Esc Anna Nery Rev Enferm. 2008;12:304-9.

33. Vasques MRG, Bello AR, Lamas CC, Correa J, Pereira JAA. $\beta$-lactamase producing enterobacteria isolated from surveillance swabs of patients in a cardiac intensive care unit in Rio de Janeiro, Brazil. Braz J Infect Dis. 2011;15:28-33.

34. Veiga AR. Condições de trabalho, fatores de risco e problemas de saúde percebidos pelo trabalhador de enfermagem hospitalar. [Dissertação]. Rio de Janeiro: Universidade do Estado do Rio de Janeiro, Faculdade de Enfermagem; 2007.

35. Winn Jr WC, Allen SD, Janda WM, Koneman EW, Procop GW, Schreckenberger PC, et al. Koneman, diagnóstico microbiológico: texto e atlas colorido. Rio de Janeiro: Guanabara Koogan; 2012.

Received: 20 November 2013

Accepted: 1 July 2014 